\title{
Hydrochemical Regime of the River Chernaya (Crimea): Environmental Aspects
}

\author{
E. I. Ovsyany, N. A. Orekhova* \\ Marine Hydrophysical Institute, Russian Academy of Sciences, Sevastopol, Russian Federation \\ *e-mail: natalia.orekhova@mhi-ras.ru
}

The hydrochemical parameters' characteristics of the river Chernaya and some its tributaries are represented based on the results of the observations in 2006-2010. The changes both of water hardness and the level of its contamination with the mineral nitrogen compounds (nitrates, nitrites and ammonium ions) are shown. The results of the investigations testify to rather noticeable anthropogenic effect (increasing at low norm of water content) upon the water chemical composition. The retrospective analysis shows that in the extreme cases mineralization, hardness, calcium and nutrient content levels in the river waters significantly exceed the hygiene and sanitary standards for drinking water. The river Chernaya waters (before the water supplying point) are constantly contaminated with the nutrients and organic matter brought by the tribute Baidarka and the slope drainage waters. Consistency of quality of the flood and low runoff waters inflowing the river Chernaya to the normative standards is assessed. Though water hardness exceeds the standards only in the extreme cases, the present trend towards growth of the river Chernaya water mineralization and contamination with organic matter and nutrients requires systemic solving of environmental problems.

Keywords: Crimea, the river Chernaya, hydrochemical characteristics, water hardness, calcium, nutrients, anthropogenic pressure.

Acknowledgements. The analysis of carbonate system components of the river Chernaya waters was carried out within the framework of RFBR research project 16-35-60006 mol_a_dk "Long-term changes in the carbon cycle characteristics of the Sevastopol Bay". The rest of the study was carried out according to state program No. 0827-2014-0010 "Complex interdisciplinary research of oceanographic processes determining the functioning and evolution of the Black Sea and the Sea of Azov ecosystems on the basis of modern methods for marine environment monitoring and grid technologies" ("Fundamental Oceanography" code).

For citation: Ovsyany, E.I. and Orekhova, N.A., 2018. Hydrochemical Regime of the River Chernaya (Crimea): Environmental Aspects. Physical Oceanography, 25(1), pp. 77-88. doi:10.22449/1573-160X-2018-1-77-88

DOI: $10.22449 / 1573-160 X-2018-1-77-88$

(C) 2018, E. I. Ovsyany, N. A. Orekhova

(C) 2018, Physical Oceanography

The river Chernaya waters accumulated in the Chernorechenskiy reservoir is the main and the only surface source of water supply in Sevastopol. When the river waters discharge into the Sevastopol Bay, they largely determine its hydrologichydrochemical regime and ecological state [1]. After the reconstruction (19771984) total volume of the Chernorechenskiy reservoir makes up 64.2 million $\mathrm{m}^{3}$, approved operational reserves are 44.3 million $\mathrm{m}^{3}$ /year. Currently this source gives $\sim 70-80 \%$ of the water consumed by the city [2]. Therefore, the analysis of ecological state of these water areas and monitoring of compliance with the regulatory requirements of the water used are the urgent problems.

Since 1916 regular stationary hydrometric work is being performed at the river Chernaya. At two gauging stations the Crimean Service for Hydrometeorology and 
Environmental Monitoring (CrimeaSHEM) measure the water flow in the upstream of the river (g/s Rodnikovskoye) as well as the flow and chemical composition of the water at the backwater (g/s Khmelnitskoye). The Main Department of Natural Resources and Ecology in Sevastopol (Sevprirodnadzor) controls the chemical composition of the water from the upstream down to the entry during the main hydrologic phases. Central laboratory of drinking water of State Unitary Enterprise "Vodokanal" and Sanitary and Epidemiological Center in the Republic of Crimea and federal city of Sevastopol control sanitary and chemical parameters of the river and reservoir water as sources of water supply. Drinking water quality requirements are determined by sanitary rules and regulations (SanPiN 2.1.4.107401, GN 2.1.5.1315-03).

According to present ideas about the biological input in the water chemical composition and its impact on human health, the cause of some diseases can be the excess or deficiency of certain macro- and microelements. Among such elements are calcium and its salts which determine the hardness of water.

Drinking water hardness is a significant criterion of the water quality. The water with high hardness index has unsatisfactory organoleptic properties and is unsuitable for industrial and household use. In addition, it is one of the factors in the development of non-infectious diseases. According to SanPiN 2.1.4.1074-01, water hardness target makes up $7 \mathrm{mg}-\mathrm{eq} / \mathrm{dm}^{3}$, according to the instruction of Chief State Sanitary Doctor this target can be increased up to $10 \mathrm{mg}-\mathrm{eq} / \mathrm{dm}^{3}$ for the centralized drinking water supply systems. Drinking of water of more than $10 \mathrm{mg}-\mathrm{eq} / \mathrm{dm}^{3}$ hardness usually leads to the development of endemic urolithiasis [3].

Currently, the city's water supply is provided by the water of both the Chernorechenskiy reservoir and a number of underground water intakes (Orlovsky, Inkermansky and others). Due to over-normative operation of some underground sources of water supply, their water does not meet the established standards for mineralization indices, total hardness, nitrate and chloride concentrations. Thus, the hardness of Orlovskiy water intake is $11-15 \mathrm{mg}-\mathrm{eq} / \mathrm{dm}^{3}$ at a mineralization (by dry residue) of up to $1630 \mathrm{mg} / \mathrm{dm}^{3}$.

According to the monitoring data, Sevprirodnadzor noted low quality of drinking water supplied to citizens of Sevastopol. Chernorechenskiy reservoir water had a satisfactory oxygen regime and was assigned to the $2^{\text {nd }}$ quality class slightly polluted water. According to the data represented in the Annual Report of Environment State, by the results of sanitary and chemical study $29 \%$ of drinking water samples from the city's water distribution system did not satisfy with SanPiN 2.1.4.1074-01 [2].

River Chernaya is not only the source of Sevastopol water supply but also the only permanent stream discharging its waters into the Sevastopol Bay. Although the river runoff is regulated, its waters exert a very appreciable influence on the hydrologic and hydrochemical regime of the bay. Thus, during the flood period the volume of river runoff can be comparable with the volume of water in the bay itself [1]. This is what determines the need to study the river waters during the Sevastopol Bay monitoring, especially in connection with the pollution of the river Chernaya downstream and significant contribution of anthropogenic sources to the nutrient supply (nitrogen and phosphorus) to the bay [4]. 
Formation of water and chemical runoff of river Chernaya is determined by two main environment-forming factors - geological conditions and climate. Geological conditions are characterized by predomination of karsting rocks (Cretaceous and Upper Jurassic carbonate deposits) [5]. The catchment area of the river Chernaya belongs to mountain forest zone of the temperate climate with mild winters and mild-hot summers. The annual norm of atmospheric precipitation ranges from $500 \mathrm{~mm}$ (foothills) to $1000 \mathrm{~mm}$ (the Main Ridge of the Crimean Mountains).

According to B. D. Zaykov classification [6], river Chernaya, along with other Crimean rivers, belongs to the group of rivers with a flood regime of the Crimean subtype. On these rivers floods are observed in any period of the year with a pronounced summer low-water. Summer low-water - a low-water summerautumn period (from May to October) - can be interrupted by irregular short-term floods of different intensity, up to catastrophic one. In the winter-spring flood period (from November to April) 80 - 85\% of the runoff passes. Summer lowwater period is characterized by the river drying up in its middle section (gorge of the river Uzundzha). The main supply of the river at this time is the groundwater runoff. The most high-water month is March, and the shallow one is September. The Chernorechensky reservoir is located in the center of the Baydar Valley. Here the river is fed by its numerous tributaries (rough in autumn and winter and dry in summer). The most significant of them is the river Baydarka.

The purpose of this work is to analyze the present conditions of river Chernaya hydrochemical regime formation and to estimate if the quality of the river water (as the main drinking water source of Sevastopol) meets regulatory requirements.

\section{Materials and methods of the study}

The work is based on the results of monitoring of the river Chernaya and Chernorechenskiy reservoir water hydrochemical structure (2002-2010). When performing the research, the data on the water hydrophysical and hydrochemical characteristics as well as on ecological state of water bodies were obtained.

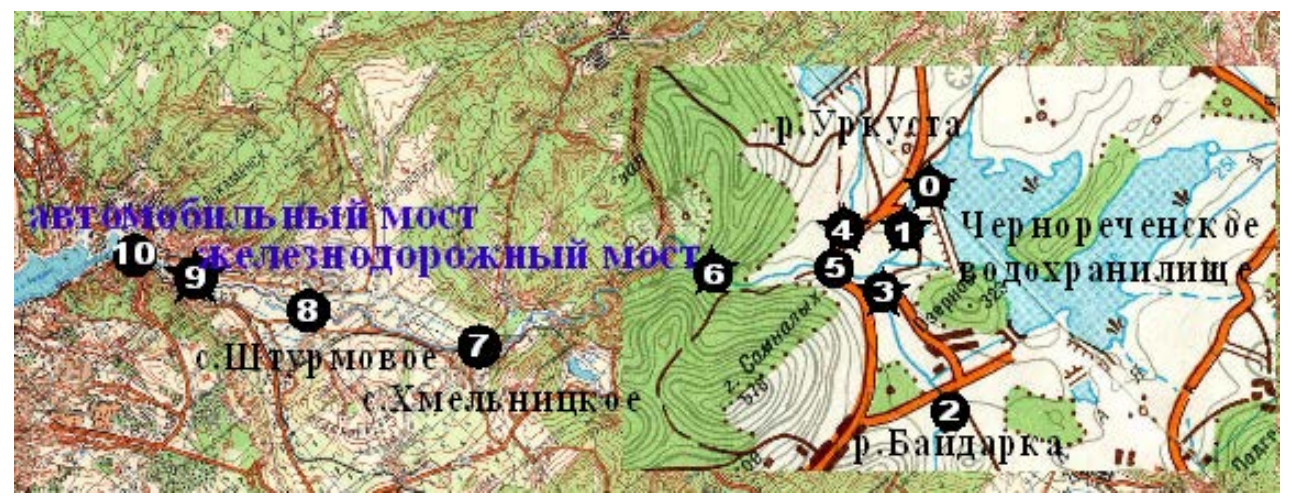

Fig. 1. Scheme of sampling stations

Sampling of water in the river and reservoir was carried out in accordance with international standards ISO 6059: 1984, ISO 6058: 1984 and methods [7, 8]. The samples were taken during the main hydrologic phases along the river course PHYSICAL OCEANOGRAPHY VOL. 25, ISS. 1 (2018) 
from the Chernorechenskiy reservoir down to the place where the river flows into the Sevastopol Bay (Fig. 1), as well as at the entry of some tributaries. The analysis of hydrochemical characteristics was carried out according to requirements of standard methods [7, 8] and regulatory documents (ISO 6059:1984, ISO 6058:1984, RD 52.24.468-2005). The oxygen content was determined by the Winkler method, the one of nutrients (phosphates, ammonium, nitrates and nitrites) - photometrically, the total mineralization - by dry residue [7]. General hardness $(\mathrm{dGH})$ and calcium content were analyzed by complexometric titration according to international standards [8] and GOST R 52407-2005. Validation of the analysis of the general water hardness and calcium content was carried out using intergovernmental reference standards IRS 0397:2002 and IRS 0399:2002.

\section{Results and discussion}

By the chemical composition the river Chernaya water (table) belongs to bicarbonate class of the calcium group $\left(\mathrm{HCO}_{3}^{-}>\mathrm{Ca}^{2+}+\mathrm{Mg}^{2+}\right)$ of medium (0.3$\left.0.5 \mathrm{~g} / \mathrm{dm}^{3}\right)$, sometimes increased $\left(>0.5-1.0 \mathrm{~g} / \mathrm{dm}^{3}\right)$ mineralization, weakly alkaline (pH 6.8-8.5) type.

Mineralization (ion composition) and river water hardness. As is known, the annual fluctuations of mineralization and components of the main ion composition of rivers are determined by the water regime, its seasonal variability and the nature of the river feeding. Estimations of multi-annual variations of the river Chernaya maximum annual expenditures allowed us to distinguish the phases of water content for the rivers of the Crimean Mountains northwestern slope: from 1950 to 1980 and from 1999 to 2010 - low water; from 1981 to 1998 - high water [9].

Due to the fact that the river has a pronounced flood regime, chemical composition natural variability depends on seasonal factors. At the maximum water content inherent for winter-spring flood when the river is a rain-fed one, the minimum values of mineralization are usually observed. In warm period during the low-water season the river is mainly fed by groundwater intake, mineralization and the content of main ion composition components increase.

Close relationship of hydrochemical regime with the water one of $\Sigma_{i}=f(Q)$ type allows one to consider the mineralization (the sum of ions, $\Sigma_{\mathrm{i}}$ ) as a function of expenditure $(Q)$ [10]. Such relationship is also characteristic of separate ion runoff components (hardness, for instance). For the river Chernaya waters a close correlation of total mineralization and hardness with water expenditures in the river over the last decade (1995-2010) is revealed. However, in the second half of 1998 a significant mineralization increase $\left(>1.0 \mathrm{~g} / \mathrm{dm}^{3}\right)$ with runoff value rise characteristic of high-water period of 1980-1990 [11] was observed. This is due to significant anthropogenic impact [12].

Seasonal multi-annual observations of the river Chernaya water content and hydrochemical regime over the observational period 1990-2010 are shown in Fig. 2. The analysis of features of intra-annual expenditure, mineralization and hardness indicates a complex mechanism of formation of the river Chernaya water chemical composition. The maximum values of hardness as well as concentration of the main ion composition and calcium are observed when expenditure increases in the flood period (Fig. 2, $a, b$ ). In the low-water period at the decrease of runoff and atmospheric precipitation norm, the distribution of hardness and calcium content during the flood period changes, in general terms, in direct proportion to the water 
expenditure: during the expenditure increase the dGH value in the water increases (Fig. 2, b).

a

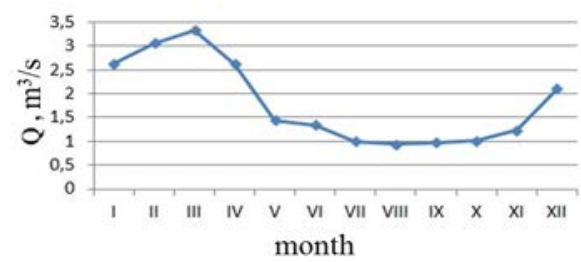

c

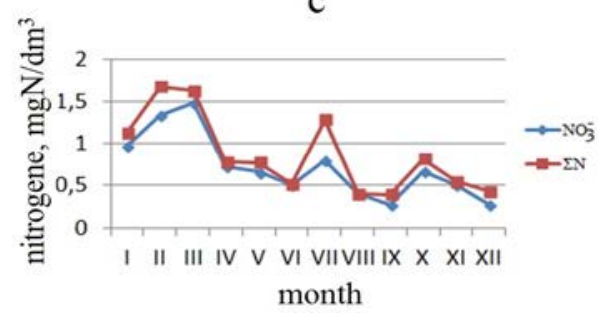

e

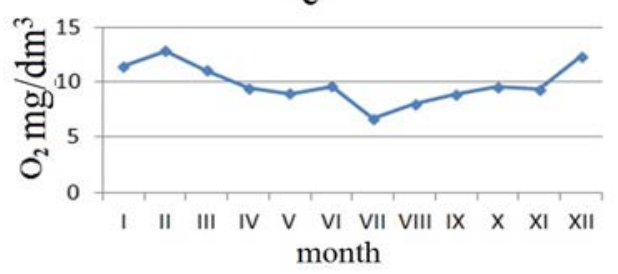

$\mathrm{b}$

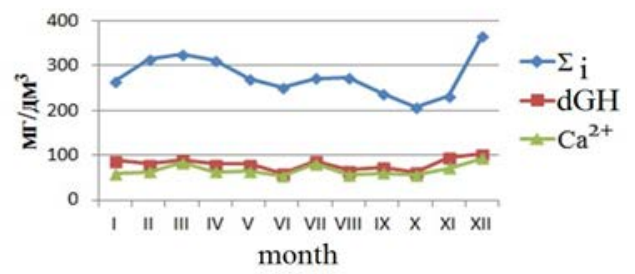

d

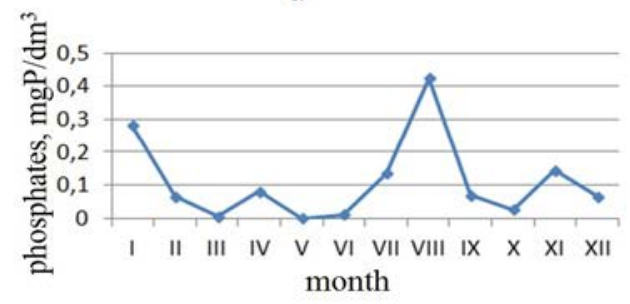

f

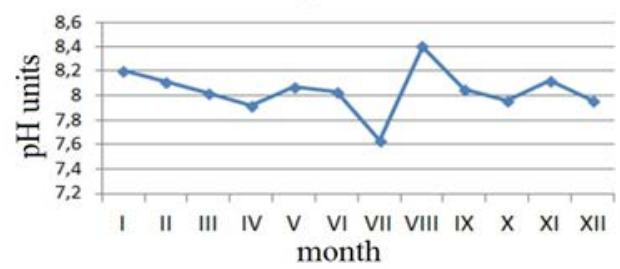

Fig. 2. Intra-annual variations of water discharge (a), mineralization, hardness and calcium content $(b)$, nitrate and total mineral nitrogen $(c)$, phosphates $(d)$ and oxygen $(e), \mathrm{pH}(f)$ in the Chernaya River water (g/s Khmelnitskoye, 1990-2010)

In our opinion, such a mechanism for the water chemical composition formation during the observation period is determined both by the nature of the water regime and by anthropogenic impact. As it was shown above, observation period refers to low-water phase of the river water content. At a low norm of water content - in the period of atmospheric precipitation absence - in the soils and rocks of the catchment area the accumulation of movable forms of ion composition chemical elements is possible. Their leaching from the underlying rocks proceeds more intensively during the flood.

Dissolved gases and nutrients. The concentration of dissolved gases (oxygen) and nutrients (nitrogen compounds, phosphates) demonstrates a dependence on expenditure; however, biogeochemical processes (respiration of hydrobionts, destruction of organic matter) and anthropogenic impact (flushing from agricultural lands, etc.) play a key role in the distribution of these characteristics.

Oxygen in the river water is at satisfactory level: its mean concentration varies from 7.7 to $15.8 \mathrm{mg} / \mathrm{dm}^{3}$. Seasonal variability of oxygen depends on the river feeding character and biochemical processes. 
During the autumn-winter flood at the rain-fed regime of the river, low temperature and active water mixing, the oxygen content is maximal (5.4$13.6 \mathrm{mg} / \mathrm{dm}^{3}$ ). During the low-water period when the oxygen concentration is mainly determined by photosynthesis and the organic matter oxidation as well as respiration of hydrobionts, its content is from $6.0 \mathrm{mg} / \mathrm{dm}^{3}$ to $10.4 \mathrm{mg} / \mathrm{dm}^{3}$ (Fig. 2, e). During our observations oxygen saturation in the river Chernaya was 88-118\% and in its left tributary, the river Baydarka, - 75-109 \%. The observed oxygen deficiency refers to the summer period. The minimum $\mathrm{pH}$ values are more characteristic of flood period (Fig. 2, $f$ ) when atmospheric precipitation is the main source of the river supply.

Intra-annual nutrient dynamics is regular and it is determined by the activity of their consumption by the plants and mineralization of organic matter, as well as their inflow with the surface runoff from the catchment area and sewage discharge, were observed. Predominant form of inorganic nitrogen for the studied rivers is a nitrate one. The minimum concentrations of nitrates are in the vegetation period (April - June), while the maximum concentrations of nitrates, the sum of the mineral compounds of nitrogen $\Sigma \mathrm{N}\left(\mathrm{NO}_{3}{ }^{-}+\mathrm{NO}_{3}{ }^{-}+\mathrm{NH}_{4}{ }^{+}\right)$and phosphates are characteristic of autumn-winter floods when the surface runoff reaches its maximum, as well as in low-water period during the oxidation of autochthonous organic matters and relative increase in the part of sewage due to decrease in natural runoff (Fig. 2, c, d). In 1990-2010 nitrate concentration varied during the year from $0-1.30 \mathrm{mgN} / \mathrm{dm}^{3}$ (during the low-water period) to $0.02-2.58$ (during the flood). Nitrites concentration did not exceed $0.037 \mathrm{mgN} / \mathrm{dm}^{3}$ during the year. The maximum ammonium concentration was observed during the summer-autumn lowwater period at $0.184 \mathrm{mgN} / \mathrm{dm}^{3}$ mean value which is two times higher than the values characteristic of the flood. Annual variations of phosphates were $0.002-$ $0.612 \mathrm{gP} / \mathrm{dm}^{3}$ with the maximum values in the flood period (Fig. 2, d). Despite the fact that the level of nutrient content in the river flow did not exceed the established maximum permissible concentration (MPC) (SanPiN 2.1.4.1074-01, GN 2.1.5.1315-03), the comparison of obtained results (table) with historical data (survey performed in 1939) when nitrogen compounds in the rivers Chernaya and Baydarka either were not detected (nitrites) or their content was very low (nitrates) - $0.07 \mathrm{mgNO}_{3} / \mathrm{dm}^{3}$ [13], indicates an increase in anthropogenic contribution and river pollution.

An increase of hardness, calcium content and mineralization is observed in the low-water period when the main source of the river feed is groundwater runoff (Fig. 2, b). Although the bicarbonate-calcium groundwater at the unloading sites in the Baidaskaya Basin has low mineralization (200-500 mg/dm ${ }^{3}$ [5], according to our observations, in the summer period the concentrations of $\mathrm{Ca}^{2+}$ and $\mathrm{dGH}$ in the river Uzundzha waters significantly exceed the ones in the river Chernaya and in the surface waters of the Chernorechenskiy reservoir. Thus, in June 2009 in the river Uzundzha entry the hardness reached $5.52 \mathrm{mg}-\mathrm{eq} / \mathrm{dm}^{3}$ at $541 \mu \mathrm{S} / \mathrm{cm}$ electric 
conductivity, while on the reservoir surface waters these parameters were $3.24 \mathrm{mg}$ eq/dm ${ }^{3}$ and $329 \mu \mathrm{S} / \mathrm{cm}$, respectively.

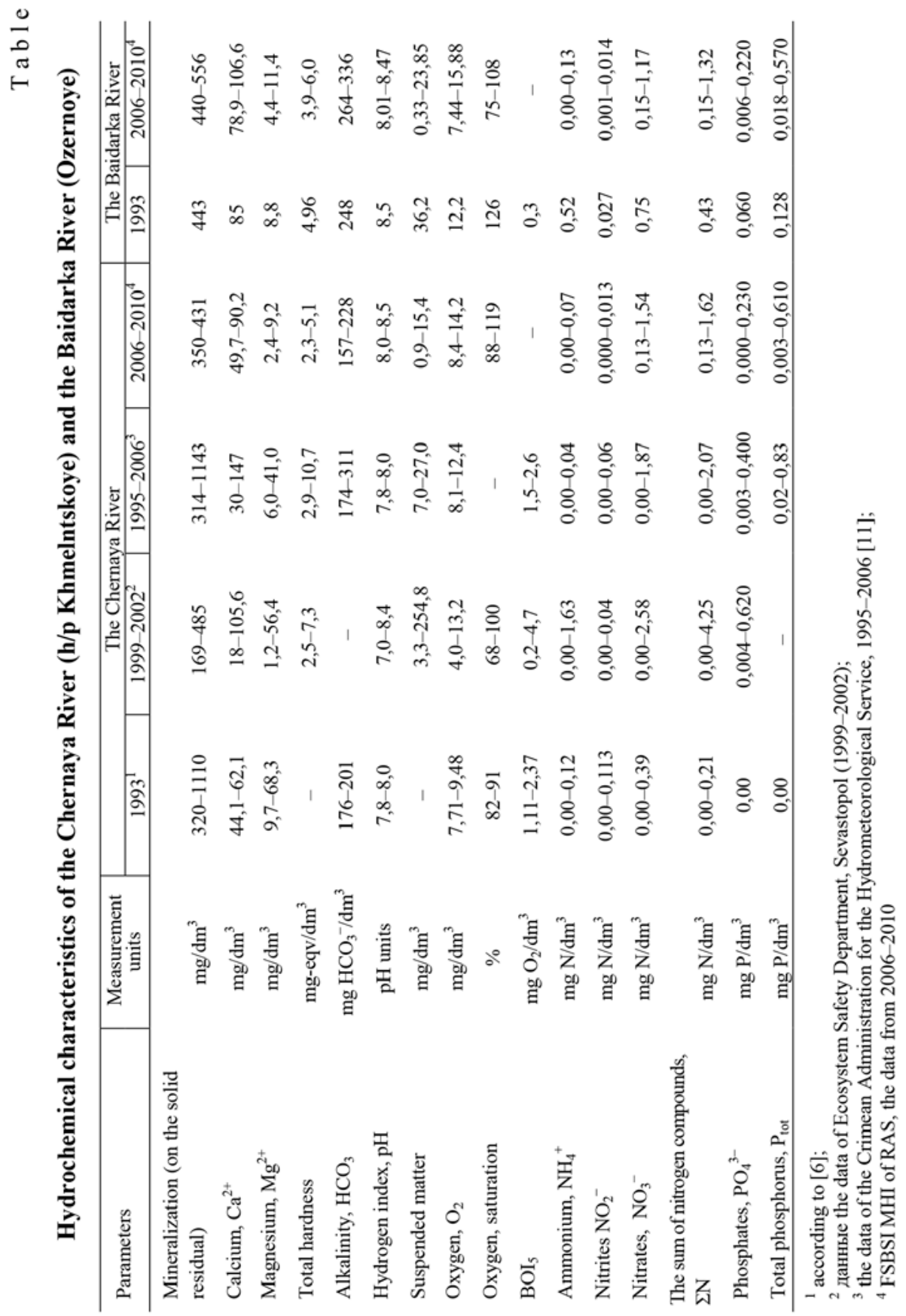


Previously it was shown that the chemical composition of waters in the river downstream is substantially transformed and the actual supply of nutrients with the downstream waters of the river is considerably (1.5-2 times) greater than the outflow [4]. Unfortunately, the pollution of the river Chernaya occurs not only in the downstream but also above the water intake for drinking water supply. This is noticeable when considering the variability of mineral substance concentrations along the river (Fig. 1, 3). It was determined that the hardness, concentrations of calcium and mineral nitrogen in the river Baydarka waters are higher than in the river Chernaya due to pollution (Fig. 1; 3, a). The increased concentrations of nitrates and $\Sigma \mathrm{N}$ are also noted in the mid-stream of the river (Fig. 1; 3, b). It should be pointed out that regulatory indicators (MPC) for these parameters were not exceeded in winter.

a

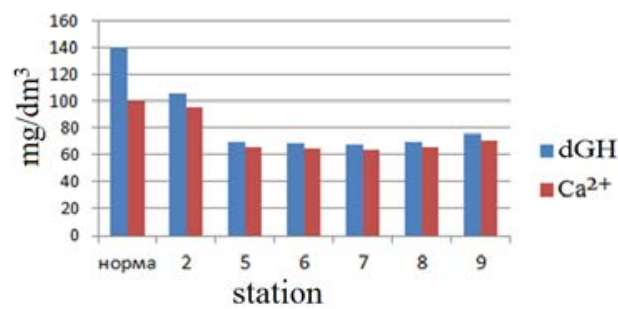

$\mathrm{b}$

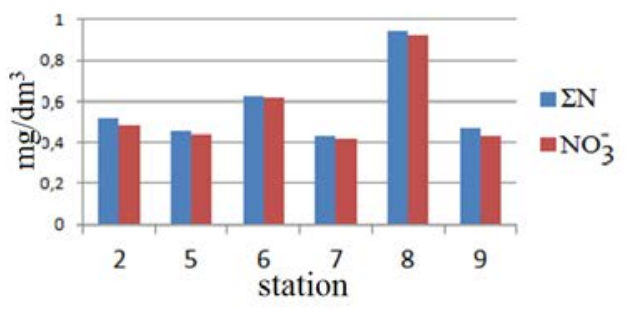

Fig. 3. Variability of the hydrochemical parameters of the river Chernaya waters along its stream 2006-2010. (st. 2 - the Baydarka River): $a$ - hardness and calcium content; $b$ - content of nitrates $\left(\mathrm{NO}_{3}-\right)$ and total mineral nitrogen $(\Sigma \mathrm{N})$

There are several types of pollution that affect the quality of river and drinking water. The most significant of them are:

- pollution of catchment area of the river and its tributaries,

- high turbidity of water during the floods,

- pollution of the Chernorecheskiy reservoir water.

The main source of pollution is an anthropogenic one. Even in water protection zones municipal sewage and contamination with household garbage are noted.

In the river Chernaya catchment area there are about thirty ponds used not only as regulators of water runoff and water consumption but also as storage ponds of wastewaters. Below the Chernorechenskiy reservoir the ponds exist on riverstributaries such as the Baydarka, the Urkusta, the Uppa and the Ay-Todorka [14].

In the conditions of failure and sometimes gross violations of requirements of main regulatory documents determining the water use procedure, both previously imposed (SanPiN 2610-82) and currently in force (SanPiN 2.1.4.1110-02), the Chernirecenskiy reservoir contamination takes place.

The main violations:

- the zones of sanitary protection are not approved in accordance with the legislation on sanitary and epidemiological welfare of the population (Part 2, Article 43 of the Water Code of the Russian Federation and SanPiN 2.1.4.1110-02); only from 2015 within the framework of Sevastopol ecological program realization the works on implementation of sanitary zones for water bodies were started [15];

- economic activities are conducted within the boundaries of sanitary protection zones; 
- since the reservoir putting into operation and until now the settlements Shirokoe, Novobobrovka, Rodnikovskoe and others, entering the second zone of the sanitary protection area, were not provided with sewage system. This leads to the intake of pollutants along the tributaries with surface slope runoff and also to the contamination of underground aqueous layers;

- more than two decades the sewage treatment plants of Orlinoye settlement did not work, and the issue of building of two sewage pressure collectors for pumping untreated sewage of Orlinoye settlement to the Ozernoye settlement treatment plant was not resolved. The sewage of Orlinoye and Tylovoye settlements came to the river Baydarka and storage ponds, and then it polluted the river Chernaya due to the dumping, infiltration and flushing under intense atmosphere precipitation. Ultimately, this led to an emergency situation: in November 2006, as a result of the dam failure, the water from the storage pond on the river Baydarka near Ozernoye settlement, where 220 thousand $\mathrm{m}^{3}$ of wastewaters were accumulated, got into the river Chernaya. More than $70 \%$ of Sevastopol population had been remaining without water supply for a week. It was stopped due to the inadequacy of water for use according to sanitary and chemical indicators $[16,17]$. Currently, the efficiency of Ozernoye settlement treatment plants is also insufficient. According to observations carried out in 2006-2010, ammonium concentration in the river Baydarka (its water gets into the river Chernaya below the reservoir water intake appliance) is more than two times higher than its values characteristic of the river Chernaya water. This indicates a constant fresh contamination as ammonium nitrogen is primarily a product of organic matter destruction in sewage. The data on the biochemical oxygen demand $\left(\mathrm{BOD}_{5}\right)$, phenol and bichromate oxidability (presented by Sevprirodnadzor in the Annual Report for 2015), which exceed the regulatory limits, also show the constant contamination of the river Chernaya and the Chernorechensky reservoir waters with nutrients and organic matter [2].

The study of the Chernorechenskiy reservoir water column in summer period (June 2002 and 2006) revealed heterogeneity of hydrochemical composition. If the content in the surface $7 \mathrm{~m}$ layer corresponds to the regulatory indices (oxygen 8.6$10 \mathrm{mg} / \mathrm{dm}^{3}$, saturation $106-116 \%$ ), then in the bottom layer of the deep-water part $(25-30 \mathrm{~m})$ there is a significant decrease in the oxygen concentration (4.2$5.7 \mathrm{mg} / \mathrm{dm}^{3}$ at $40-75 \%$ saturation). The main cause is the oxygen consumption on allochthonous and autochthonous organic matter oxidation during the summer stagnation when the aeration of the water layers is hindered and the reservoir is fed mainly by groundwater with the minimum oxygen content. Nutrient content here does not exceed regulatory limits but it is about 10 times higher than in the surface water layer [18]. In the near-bottom layer the hardness - 3.76-3.84 mg-eq/ $/ \mathrm{dm}^{3}$ (at $3.06 \mathrm{mg}-\mathrm{eq} / \mathrm{dm}^{3}$ average value in the surface layer) and calcium concentration in the bottom waters are significantly higher. This is also due to groundwater feeding.

Another factor affecting the drinking water quality is high turbidity of water (suspended matter concentration) during the floods (up to $250 \mathrm{mg} / \mathrm{dm}^{3}$, see the Table), which creates certain difficulties in water treatment and leads to excess of the regulatory values for turbidity.

From the analysis of interannual variation of mineralization $\left(\Sigma_{\mathrm{i}}\right)$, hardness (dGH) and calcium for Khmelnitskoye waterworks facility (Fig. 4) it follows that 
interannual variability of the considered parameters usually does not exceed the established regulatory parameters except for the extreme results obtained in 1998. At the same time, there is a trend for the increase of mineralization of the Crimean river waters, including the river Chernaya, as a result of anthropogenic pressure [6].

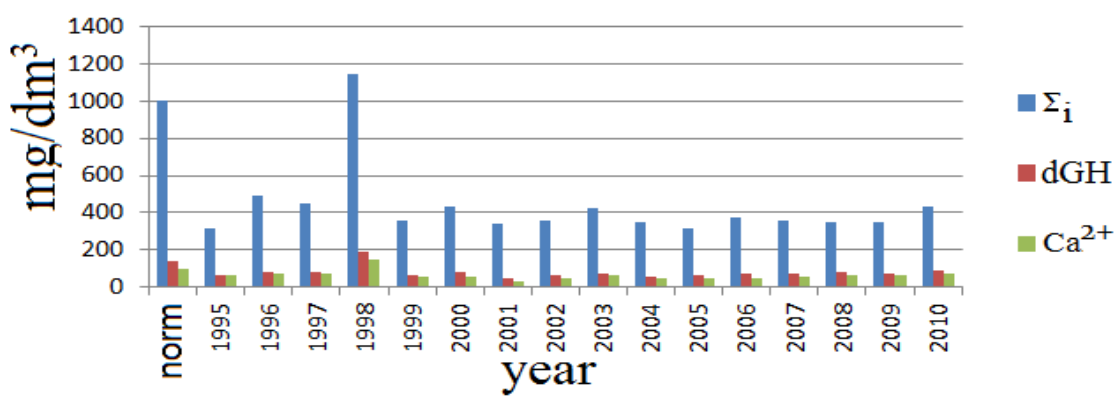

Fig. 4. The river Chernaya: interannual variability of mineralization, hardness and calcium content (g/s Khmelnitskoye, 1995-2010)

\section{Conclusion}

Thus, due to the absence of sewage system in the settlements located within the water protection zone, the pollution of the river Chernaya and underground aqueous layers occurs during surface-slope runoff and infiltration of wastewater from storage pounds. As a result, the quality of water getting to the Waterworks Facility No. 3 for preparation is so low that it is not always possible to perform its normative treatment, since the treatment capabilities of the waterworks facility are not designed for such pollution level.

It should be noted that the issue of supplying high-quality drinking water to Sevastopol cannot be considered satisfactory. At the current state of water protection measures in the catchment of the river Chernaya and in the sanitary protection zone of the Chernorechenskiy reservoir, and also in the absence of an alternative surface water source at present, the city is not immune to extreme situations such as those that occurred in 1998 and 2006. The problem of protecting the catchment areas and river waters from pollution by domestic wastewaters requires urgent consideration. The demand for quality drinking water will increase with the growth of the population, with the development of the tourism and industry. At an increase in the demand for drinking water, the attempt to increase the proportion of groundwater (the quality of which often does not meet regulatory requirements) in the total volume of water supply does not compensate the deficit of water suitable for consumption. With the current trend of the water mineralization increase and the growth of pollution, it is necessary to introduce systematic environmental measures aimed to solve the identified problems.

The authors of the article express their gratitude to the staff of Sea Biogeochemistry Department and personally to S.I. Kondrat'ev for help in obtaining full-scale data when sampling and performing chemical analysis. 


\section{REFERENCES}

1. Repetin, L.N., Gordina, A.D., Pavlova, E.V., Romanov, A.S. and Ovsyany, E.I., 2003. Vliyanie Okeanograficheskikh Faktorov na Ekologicheskoe Sostoyanie Sevastopol'skoy bukhty (Chernoe More) [Affect of Oceanographic Factors upon the Ecological State of the Sevastopol Bay (the Black Sea)]. Morskoy Gidrofizicheskiy Zhurnal, (2), pp 66-80 (in Russian).

2. Ezhegodnyy Doklad o Sostoyanii i ob Okhrane Okruzhayushchey Sredy Goroda Federal'nogo Znacheniya Sevastopolya za 2015 God [Annual Report about Environmental State and Protection of the Federal City of Sevastopol]. Sevastopol: Sevprirodnadzor, 2016. 147 p. Available at: https://sevastopol.gov.ru/files/iblock/d03/ecogosdoklad_sev_2015.pdf [Assessed 04 September 2017] (in Russian).

3. Eliseev, Yu.Yu., Alekseev, N.I., Antonova, A.N., Zhukov, V.V., Kochkin, V.P. and Lutsevich, I.N., 2007. Obshchaya Gigiena i Ekologiya Cheloveka [General Human Hygiene and Ecology]. Moscow: EKSMO, 402 p. (in Russian).

4. Ovsyany, E.I., Artemenko, V.M., Romanov, A.S. and Orekhova, N.A., 2007. Stok Reki Chernoy kak Faktor Formirovaniya Vodno-Solevogo Rezhima i Ekologicheskogo Sostoyaniya Sevastopol'skoy Bukhty [The Chernaya River Discharge as a Factor Affecting the Watter-Salt Regime forming and Ecological State of the Sevastopol Bay]. In: MHI, 2011. Ekologicheskaya Bezopasnost' Pribrezhnoj i Shel'fovoj Zon i Kompleksnoe Ispol'zovanie Resursov Shel'fa [Ecological Safety of Coastal and Shelf Zones and Comprehensive Use of Shelf Resources]. Sevastopol: MHI NANU. Iss. 15, pp. 57-65 (in Russian).

5. Shestopalov, V.M., Boguslavskiy, A.S., Klimchuk A.B., Fesenko, A.V. and Gordenko, G.E., 2008. Modelirovanie Resursov Podzemnykh Vod Yugo-Zapadnoy Chasti Gornogo Kryma [Modeling of Groundwater Resources of the South-Western Part of Mountainous Crimea]. Geologiya i Poleznye Iskopaemye Mirovogo Okeana, (4), pp. 5-28 (in Russian).

6. Timchenko, Z.V., 2008. Vodnye Resursy i Ekologicheskoe Sostoyanie Malykh Rek Kryma [Water Resources and Ecological State of the Small Rivers of Crimea]. Simferopol: Dolya, 152 p. (in Russian).

7. Gosudarstvennyy Kontrol' Kachestva Vody [The State Control of Water Quality]. Moscow: IPK Izdatel'stvo standartov, 2003, 776 p. (in Russian).

8. Fomin, G.S., 2000. Voda. Kontrol' Khimicheskoy, Bakterial'noy i Radiatsionnoy Bezopasnosti po Mezhdunarodnym Standartam. Entsiklopedicheskiy Spravochnik [Water. The Chemical, Bacterial and Radiation Safety Control in Line with International Standards]. Moscow: Protektor. 839 p. (in Russian).

9. Ovcharuk, V.A. and Todorova, E.I., 2014. Statisticheskie Parametry Maksimal'nykh Raskhodov Vody i Sloev Pavodochnogo Stoka Dlya Rek Gornogo Kryma [Statistical parameters maximum water discharge and layers peak flow rivers of mountain Crimea]. Geopolitika i Ekogeodinamika Regionov, 10(1). pp. 766-770. (in Russian).

10. Alekin, O.A., 1970. Osnovy Gidrokhimii. [Hydrochemistry Principles]. Leningrad: Gidrometeoizdat, 442 p. (in Russian).

11. Osadchiy, V.I., Nabivanets', B.Y., Osadchaya, N.M. and Nabivanets', Yu.B., 2008. Gidrokhimichniy Dovidnik: Poverkhnevi Vodi Ukraïni. Gidrokhimichni Rozrakhunki. Metodi Analizu [Hydrochemistry Manual: Surface Waters of Ukraine. Hydrochemical Calculations. Methods of Analysis]. Kiev: Nika-Tsentr, 656 p. (in Ukrainian).

12. Osadchiy, V.I., 2000. Osnovni Tendentsiï Formuvannya Khimichnogo Skladu Poverkhnevikh vod Ukraïni u 1995-1999 rr. [Main Tendencies in Chemical Composition Formation of Surface Waters of Ukraine in 1995-1999]. In: UkrNDGMI, 2000. Naukovi Pratsi UkrNDGMI. Kiev. Iss. 248, pp. 138-153 (in Ukrainian).

13. Alekin, O.A., 1948. Gidrokhimiya Rek SSSR. Ch.2 [Hydrochemistry of the Rivers in USSR. Ed. 2]. Leningrad: Gidrometeoizdat. Trudy GGI, 10(64), pp. 144-148 (in Russian).

14. Lisovskiy, A.A., Novik, V.A., Timchenko, Z.V. and Mustafaeva, Z.R., 2004. Poverkhnostnye Vodnye Ob'ekty Kryma [Crimean Surface Waters' Bodies]. Simferopol: Reskomvodkhoz ARK. 114 p. (in Russian). 
15. Gosudarstvennaya Programma Goroda Sevastopolya "Okhrana Okruzhayushchey Sredy i Ratsional'noe Ispol'zovanie Prirodnykh Resursov Goroda Federal'nogo Znacheniya Sevastopolya na 2015-2017 Gody" [The State Program of Sevastopol "Environmental Protection and Rational Use of Natural Resources of the Federal City of Sevastopol in 20152017"]. Available at: http://crimea.regnews.org/doc/bq/ne.htm [Assessed: 01 September 2017] (in Russian).

16. Prud-otstoynik “Otklyuchil” Sevastopol' ot Vody [Settling Pond "Turned Off" Sevastopol from Water Supply] Available at: http://www.totalua.com/2006-11-10/print20617.html [Accessed: 01 September 2017] (in Russian).

17. Sluchaynost', Bezalabernost' ili Zlaya Volya? [Randomness, Disorder or Evil Will?]. Slava Sevastopolya, 10 November 2006. Available at: https://slavasev.ru/2006/11/10/sluchaynostbezalabernost-ili-zlaya-volya/ [Accessed: 01 September 2017] (in Russian).

18. Artemenko, V.M., Badyukov, D.D., Ivanov, V.A., Kondrat'ev, S.I., Krasovskiy, Zh.L., Lyashenko, S.V. and Yastreb, V.P., 2003. Gidrologo-Gidrokhimicheskie Osobennosti Vod Chernorechenskogo Vodokhranilishcha v Letniy Period [Hydrologycal and Hydrochemical Features of Chernorechenskiy Reservoir in Summer Time]. In: MHI, 2011. Ekologicheskaya Bezopasnost' Pribrezhnoj i Shel'fovoj Zon i Kompleksnoe Ispol'zovanie Resursov Shel'fa [Ecological Safety of Coastal and Shelf Zones and Comprehensive Use of Shelf Resources]. Sevastopol: MHI NANU. Iss. 9, pp. 67-75 (in Russian).

\section{About the authors:}

Evgeniy I. Ovsyany - Research Associate, Marine Biogeochemistry Department, FSBSI MHI (Sevastopol, Russian Federation), ORCID ID: 0000-0002-6093-5102, EugeneOvsyany@yandex.ru.

Natalia A. Orekhova - Head of Marine Biogeochemistry Department, FSBSI MHI (Sevastopol, Russian Federation), Ph.D. (Geogr.), ORCID ID: 0000-0002-1387-970X; ResearcherID: I-1755-2017; natalia.orekhova@mhi-ras.ru.

\section{Contribution of the co-authors:}

Natalia A. Orekhova - scientific supervision of the research; participation in the discussion of the article materials; discussion of the study results; analysis and generalization of the research results, formulation of the conclusions.

Evgeniy I. Ovsyany - setting out the objectives and tasks of the research; analysis of materials on the research theme; formulation of the conclusions.

All authors have read and approved the final manuscript.

The authors declare that they have no conflict of interest. 